International Journal of Biology, Pharmaey and Allied Seiences (IJBPAS)

'A Bridges Betueen caboratory and QRendo'

www.ibpas.com

\title{
DETERMINATION OF HEAVY METALS IN FROZEN FISH IMPORTED BY FISHERY COMPANIES OF BENIN
}

\section{ELISABETH YAP ${ }^{*}$, JUDICAEL AP ${ }^{1}$, AND ROMEO AM ${ }^{1}$}

1: Laboratoire de Recherche en Biologie Appliquée (LARBA), Département de Génie de

l'Environnement, Ecole Polytechnique d'Abomey-Calavi (EPAC), Université d'Abomey-Calavi (UAC), 01 BP 526, Cotonou, BENIN

*Corresponding Author: Dr. Elisabeth YAP: E Mail: yehouenoue@yahoo.fr Tel: 00 (229)958418 07

Received $4^{\text {th }}$ Aug. 2020; Revised 20 ${ }^{\text {th }}$ Sept. 2020; Accepted $15^{\text {th }}$ Oct. 2020; Available online $1^{\text {st }}$ July 2021

\section{https://doi.org/10.31032/IJBPAS/2021/10.7.5108}

\begin{abstract}
In order to fill its fish deficit, Benin imports more than 45,000 tons of frozen fish each year. According to some authors, this dependence on fish products imports could be a great threat to food security. The objective of this study is to assess the level of heavy metal contamination of frozen fish species consumed by Beninese populations. Heavy metals such as cadmium, lead, copper and zinc were determined by atomic absorption spectrophotometry in fresh, fried and cooked fish. Results showed that cadmium levels in fresh fish ranged from 0 to $0.004 \mathrm{mg} / \mathrm{kg}$, lead 0 to $0.008 \mathrm{mg} / \mathrm{kg}$, copper 0 to $0.31 \mathrm{mg} / \mathrm{kg}$ and zinc from 0.1205 to $0.2785 \mathrm{mg} / \mathrm{kg}$. In the same species of cooked fish, cadmium concentrations ranged from 0.003 to $0.006 \mathrm{mg} / \mathrm{kg}$, lead from 0 to $0.0165 \mathrm{mg} / \mathrm{kg}$, copper from 0 to $0.033 \mathrm{mg} / \mathrm{kg}$ and zinc from 0.159 to $0,33 \mathrm{mg} / \mathrm{kg}$. In the same fried fish species, cadmium concentrations ranged from 0.0035 to $0.009 \mathrm{mg} / \mathrm{kg}$, lead from 0 to $0.0025 \mathrm{mg} / \mathrm{kg}$, copper from 0.0065 to $0.058 \mathrm{mg} / \mathrm{kg}$ and zinc from 0.109 to $0.222 \mathrm{mg} / \mathrm{kg}$ ). The levels of heavy metals are all below the standards accepted by FAO / WHO. The consumption of these fish would therefore have no negative effect on the population's health. Depending on the two cooking methods, there is a reduction of heavy metal concentrations in some fish species. Although the concentrations of heavy metals are not worrying, populations must be careful and must vary their diets to guarantee a better health.
\end{abstract}

Keywords: Heavy metals, imported frozen fish, Cotonou, Benin 


\section{INTRODUCTION}

A healthy population is the first development factor of any nation [1]. The well-being of this population depends on its diet quality [2]. That is why governments often established surveillance rules to ensure food quality and safety for consumers. Nutritional food quality monitoring has greatly increased since the 19th century with the birth of national consumer associations and global standardization bodies [3]. But despite this watch, most of the food consumed in recent years is not free of chemical residues and this has consequences in the short, medium and long term for the human body $[4,5]$.

In Benin, fish production is provided by rivers and other water bodies. In recent years, population needs for fish have increased and the amount of fish caught has dropped by about 15\% from 2003 to 2008 [6]. To fill this gap, Benin imports more than 45,000 tons of frozen fish every year [6]. This dependence on imported fish poses a great threat to food security [7]. Indeed, fish species are bioaccumulative. They are able to absorb and concentrate in their body some chemicals such as heavy metals. Since they occupy a prominent place on Beninese people's plates, their contamination could pose a public health problem. Although several studies showed the contamination of fish caught in the country's rivers and streams [8-13], few were interested in the imported fish contamination. This study proposes to evaluate the contamination level of heavy metals in frozen fish species consumed by Beninese populations.

\section{MATERIALS AND METHODS}

\section{1-Study area}

Five marketing companies of imported frozen fish of Cotonou commonly called "fishmarket".

\section{2-METHODS}

\subsection{1- Fish sampling}

Fishes were collected from importing frozen fish sellers. Sampled fish caught were immediately kept cool in cool boxes until they were sent to laboratory for analysis.

\subsection{2- Choice of fish species and heavy metals}

Fish choice criteria are their availability throughout the year and their appreciation by the population. The species sampled are: Euthynnus alletteratus, Tilapia guineensis, Merluccius merluccius, Dentex angolensis, Pseudotolithus senegalensis, Albula vulpes, Pseudotolithus typus, Cynoglossus canariensis, Thrachurus trachurus. Ten fish were collected per species.

Heavy metals such as lead and cadmium are chosen in this study because they were the most toxic to humans and more frequently found in the environment [14]. Copper and zinc were associated with them for two 
reasons: firstly they were not chemically metals and then they were only toxic beyond a certain threshold.

\subsubsection{Method of analysis}

In order to better assess the risks faced by consumers, it was agreed to analyze the flesh (muscle tissue), which is the portion consumed by the population. Thus, the flesh of 10 fish per species was mixed and divided into 3 parts: the first was analyzed fresh, the second part was boiled with demineralized water and the third fried in oil. They were analyzed. Fish samples were mineralized in a programmable muffle furnace and then analyzed by atomic absorption spectrophotometry with a Spectr AA110 atomic absorption spectrophotometer and its control computer.

\subsubsection{Statistical analysis}

Heavy metal contents from the analyzed fish species were submitted to a mixedeffect linear model in order to evaluate their variation according to the cooking method. The cooking mode (fresh, cooked and fried) and the species factor were considered fixed and the repetition as random. The mixedeffect linear model was made possible by the lmer function of the lmerTest package [15]. Adjusted averages were obtained by the lsmeans function of the lsmeans package [16]. The ggplot2 package [17] presented these averages graphically.
In order to evaluate the two-to-two correlation between the various heavy metals analyzed, corrplot function of the corrplot package [18] were used with the Pearson method. All analyzes and graphs were done with the R 3.5.1 software.

\section{RESULTS AND DISCUSSION}

\subsection{Heavy metal content in fresh fish, cooked and fried}

The results showed the presence of cadmium, lead, copper and zinc in several analyzed fish species according to Figure 1.

In fresh fish, the average cadmium content ranged from 0 to $0.004 \mathrm{mg} / \mathrm{kg}$. Lead, copper and zinc ranged from 0 to $0.008 \mathrm{mg}$ $/ \mathrm{kg}, 0$ to $0.031 \mathrm{mg} / \mathrm{kg}$ and 0.145 to 0.2785 $\mathrm{mg} / \mathrm{kg}$, respectively. Euthynnus alletteratus species had the highest concentration of cadmium, the highest concentration of lead and copper was found in Thrachurus trachurus and Pseudotolithus senegalensis species had the most zinc.

In cooked fish, the average levels of cadmium, lead, copper and zinc ranged from 0.003 to $0.006 \mathrm{mg} / \mathrm{kg}$, from 0 to $0.0165 \mathrm{mg} / \mathrm{kg}$, from 0 to $0.033 \mathrm{mg} / \mathrm{kg}$ and from 0.159 to $0.33 \mathrm{mg} / \mathrm{kg}$. Albulavulpes species contained both cadmium, lead, copper and zinc. As for fried fish, the average cadmium, lead, copper and zinc contents are between 0.0035 and $0.009 \mathrm{mg} / \mathrm{kg}$, respectively, 0 
and $0.0025 \mathrm{mg} / \mathrm{kg}, 0.0065$ and $0.058 \mathrm{mg} /$ $\mathrm{kg}, 0.109$ and $0.222 \mathrm{mg} / \mathrm{kg}$. The most elevated concentrations of cadmium, lead, copper and zinc are in Merluccius merluccius, Euthynnus alletteratus, Pseudotolithus senegalensis and Albula vulpes, respectively. Heavy metal levels do not exceeds FAO and WHO standards in all of these fish species. The consumption of these fish could therefore have no negative effect on the population's health.

Statistical analysis of these results showed that, with the exception of zinc, the content of other heavy metals such as cadmium, lead and copper varied significantly depending on the method of cooking and the species, as well as following the interaction of these two factors $(p<0.05)$ (Table 1). This variation of heavy metal content in imported frozen fish may be due to the phenomenon of uptake, diffusion and excretion at the time of fish capture.

\subsection{Effects of cooking methods on the fish} heavy metals content

Heavy metals were measured in fresh fish, cooked fish and fried fish. Table 2 shows the comparison of heavy metal contents in the different forms of cooking.

It can be seen from this table that the trend in different metal contents varied from one species to another depending on the cooking methods of the fish. In fact, depending on the fish species, there were a decrease or increase of cadmium, lead, copper and zinc content depending on whether the fish is fresh, fried or cooked. It can therefore be deduced that both cooking methods have positive effect on the heavy metal levels reduction in some fish species. In other fish, the effect is negative. This behaviour could be attributed to several parameters such as fish size, oil absorption, water loss and metal evaporation during cooking [19].

Statistical analysis revealed more or less strong correlation between cadmium and lead in fresh fish. For cooked fish, the correlation is strong and positive between lead and copper while for fried fish, the correlation between metals is low or even negative (Figure 2). 

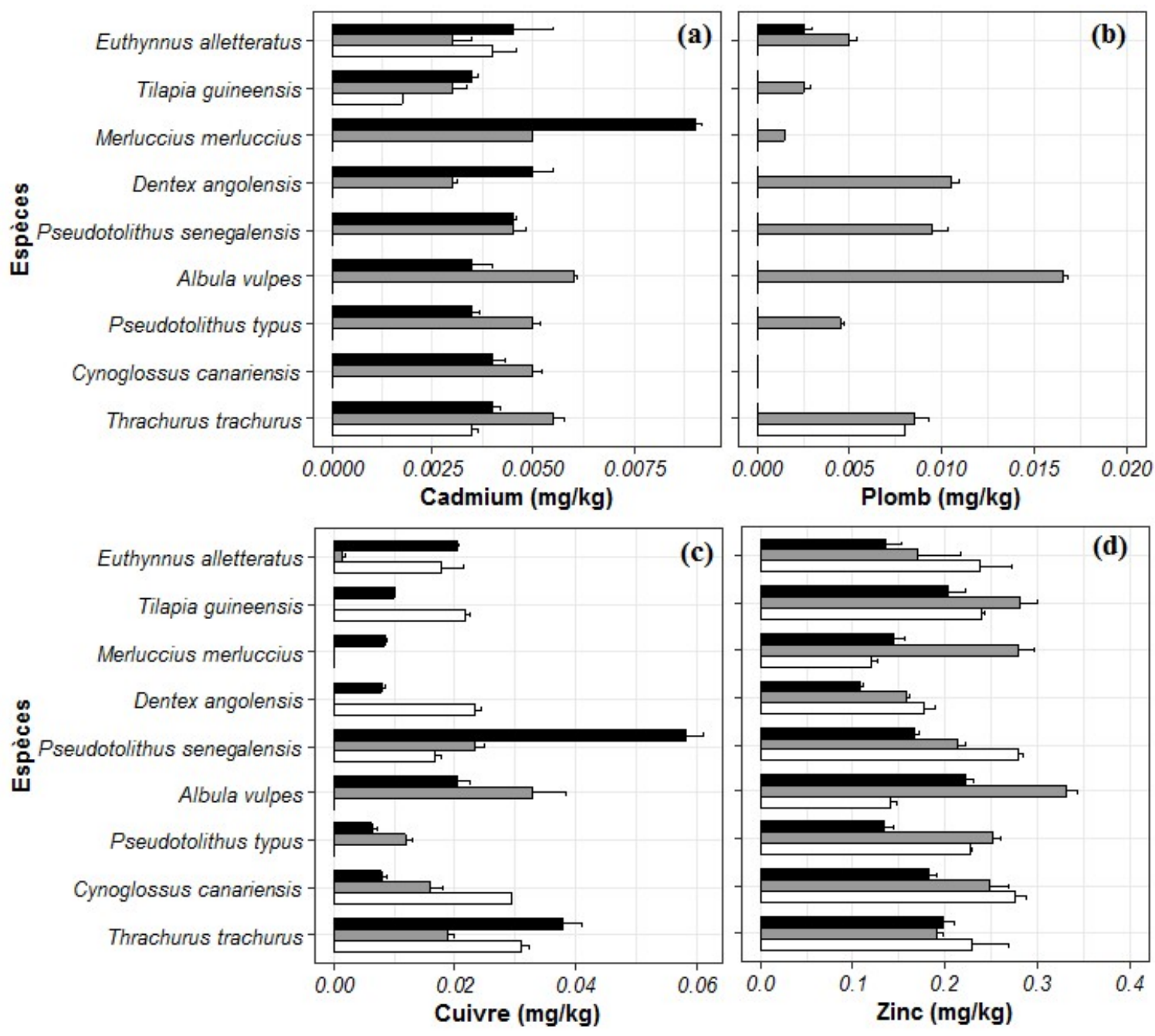

Figure 1 : Variation in Heavy Metal Levels in Imported Frozen Fish

Table 1 : Results of the mixed-effect linear model on the variation of heavy metal contents

\begin{tabular}{cccccccccc}
\hline & & \multicolumn{2}{c}{ Cadmium } & \multicolumn{2}{c}{ Plomb } & \multicolumn{2}{c}{ Cuivre } & \multicolumn{2}{c}{ Zinc } \\
\hline MC & ddl & F & Prob & F & Prob & F & Prob & F & Prob \\
E & $\mathbf{2}$ & $\mathbf{2 , 2 5}$ & $\mathbf{0 , 1 1 6}$ & $\mathbf{2 9 , 7 3}$ & $<\mathbf{0 , 0 0 1}$ & $\mathbf{3 , 7 4}$ & $\mathbf{0 , 0 3 0}$ & $\mathbf{0 , 2 3}$ & $\mathbf{0 , 7 9 2}$ \\
MC $:$ E & $\mathbf{8}$ & $\mathbf{5 , 6 6}$ & $<\mathbf{0 , 0 0 1}$ & $\mathbf{9 , 2 9}$ & $<\mathbf{0 , 0 0 1}$ & $\mathbf{6 , 4 4}$ & $<\mathbf{0 , 0 0 1}$ & $\mathbf{1 , 7 9}$ & $\mathbf{0 , 0 9 9}$ \\
ICC $_{\text {Répétition }}$ & $\mathbf{1 6}$ & $\mathbf{5 , 6 5}$ & $<\mathbf{0 , 0 0 1}$ & $\mathbf{1 4 , 7 5}$ & $<\mathbf{0 , 0 0 1}$ & $\mathbf{6 , 3 6}$ & $<\mathbf{0 , 0 0 1}$ & $\mathbf{1 , 4 3}$ & $\mathbf{0 , 1 6 4}$ \\
\hline
\end{tabular}

CM: Cooking mode; E: Species; ddl: degree of freedom; F: Fischer statistic; Prob: Probability of significance

Table 2 : Comparison of the contents of heavy metals in the different forms of cooking

\begin{tabular}{|c|c|c|c|c|c|c|c|c|c|c|c|c|}
\hline \multirow{2}{*}{ Fish Species } & \multicolumn{3}{|c|}{ Cadmium (mg/kg) } & \multicolumn{3}{|c|}{ Plomb (mg/kg) } & \multicolumn{3}{|c|}{ Cuivre (mg/kg) } & \multicolumn{3}{|c|}{ Zinc (mg/kg) } \\
\hline & Frais & Cuit & Frit & Frais & Cuit & Frit & Frais & Cuit & Frit & Frais & Cuit & Frit \\
\hline Cynoglossus canariensis & $<0,001$ & 0,005 & $<0,001$ & $<0,001$ & $<0,001$ & $<0,001$ & $\mathbf{0 , 0 3}$ & 0,016 & 0,01 & 0,28 & 0,25 & 0,18 \\
\hline Albula vulpes & $<0,001$ & 0,006 & $<0,001$ & $<0,001$ & $\mathbf{0 , 0 1 7}$ & $<0,001$ & $<0,001$ & $\mathbf{0 , 0 3 3}$ & 0,02 & 0,14 & $\mathbf{0 , 3 3}$ & 0,22 \\
\hline Pseudotolithus senegalensis & $<0,001$ & 0,005 & 0,01 & $<0,001$ & & & 0,017 & 0,024 & 0,06 & 0,28 & 0,22 & $\mathbf{0 , 1 7}$ \\
\hline Dentex angolensis & $<0,001$ & 0,003 & $\mathbf{0 , 0 1}$ & $<0,001$ & 0,011 & & 0,024 & $<0,001$ & $\mathbf{0 , 0 1}$ & $\mathbf{0 , 1 8}$ & 0,16 & $\mathbf{0 , 1 1}$ \\
\hline Euthynnus alletteratus & 0,004 & $\mathbf{0 , 0 0 3}$ & 0,01 & $<0,001$ & 0,005 & 0,003 & 0,018 & 0,002 & 0,02 & 0,24 & $\mathbf{0 , 1 7}$ & 0,14 \\
\hline
\end{tabular}




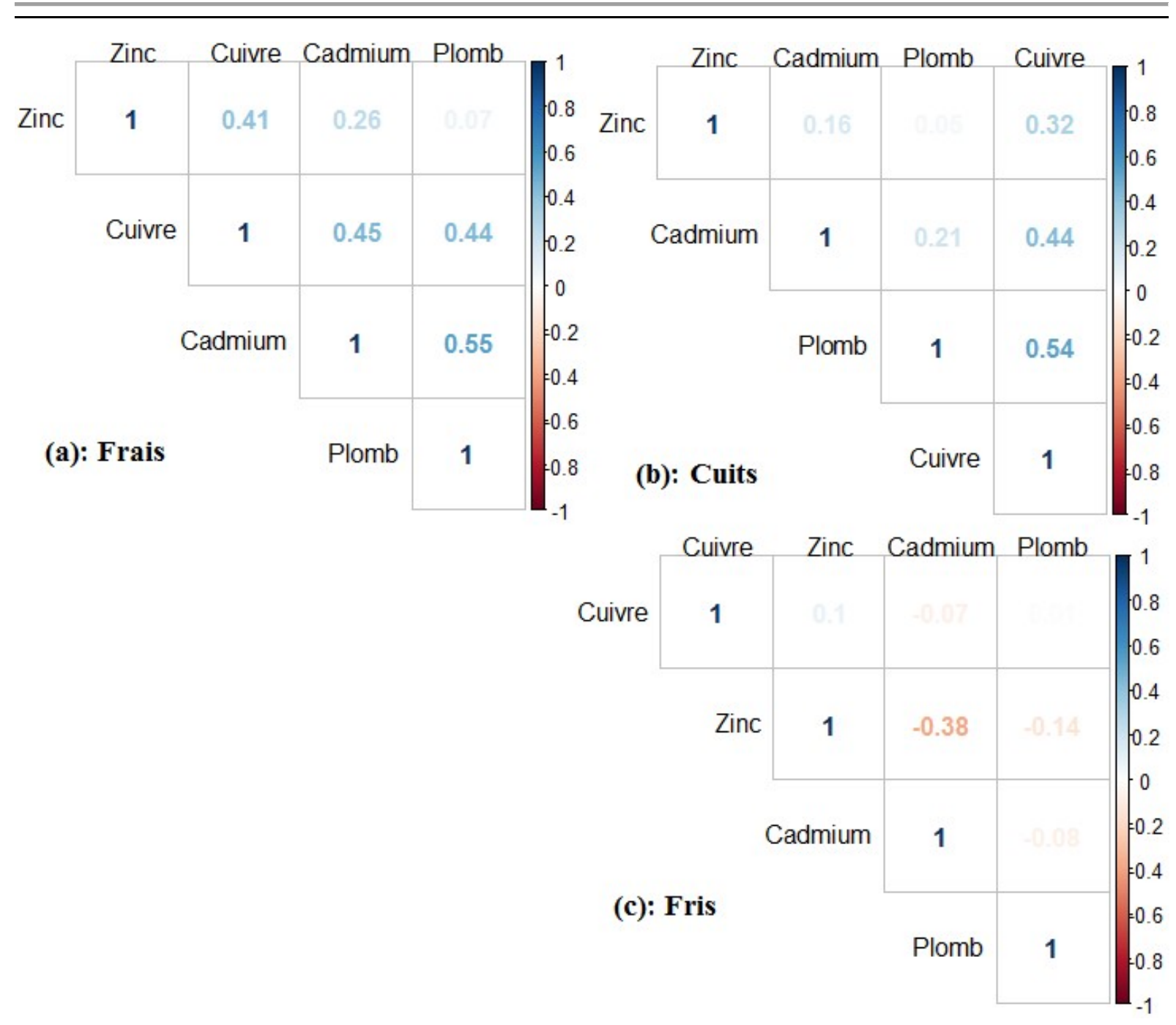

Figure 2 : Correlation between heavy metals found in imported frozen fish

\subsection{DISCUSSION}

In this study, heavy metal values obtained in fresh fish analyzed are lower than those recorded in fresh fish sampled in Saudi Arabian markets by Alturiqi and Albedair in 2012 [20] in which concentrations levels varied between 1.17 and $4.25 \mu \mathrm{g} / \mathrm{g}$ for cadmium, between 3.24 and $9.17 \mu \mathrm{g} / \mathrm{g}$ for lead, between 2.3 and $12.05 \mu \mathrm{g} / \mathrm{g}$ for copper and between 16.79 and $49.43 \mu \mathrm{g} / \mathrm{g}$ for zinc. Our results are significantly lower than those obtained in Scomber scombrus, frozen in Nigeria, where cadmium and lead levels are $2.192 \mathrm{mg} / \mathrm{kg}$ and $15.13 \mathrm{mg} / \mathrm{kg}$ respectively [21]. According to Oluyemi and Olabanji [22], the lead (0.42-0.49 $\mu \mathrm{g} /$ g) and cadmium (0.04-0.07 $\mu \mathrm{g} / \mathrm{g})$ levels obtained in frozen fish (Scomber scombrus, Trachurus trachurus, Salmo solar, Clupea harengus and Sardinella tawilis) imported to Nigeria were higher than those in this study. The average lead and cadmium concentrations recorded by these authors in Trachurus trachurus are respectively 46 and 15 times higher than those obtained in the same species of fish in this study. The 
dissimilarity between these results and those recorded in this study may be related to the origin of the fish, their ecological zone and their habitat.

According to cooked fish, the results of this work are inferior to those obtained by Huque et al. [23] in Pampus argenteus fish samples boiled and taken along Bengali Bay in Bengali, where average recorded concentrations are $6.03 \mathrm{mg} / \mathrm{kg}, 15.34 \mathrm{mg} /$ $\mathrm{kg}, 3.55 \mathrm{mg} / \mathrm{kg}$ and $24.82 \mathrm{mg} / \mathrm{kg}$ for cadmium, lead, copper and zinc, respectively. Obodai et al. study in Ghana [24] on boiled Sarotherodon melanotheron also gave average concentrations of cadmium $(0.364 \mathrm{mg} / \mathrm{kg})$ and lead (12.154 $\mathrm{mg} / \mathrm{kg}$ ) that were higher than those found in all the fish analyzed in this study. However, high levels of lead in food would lead to kidney failure and damage to the human liver. Also, fatal ingestions of cadmium exceeding $350 \mathrm{mg}$ could produce shock and renal failure [20].

Concerning fried fish, results of this study are much lower than those obtained by Tawfik [25] in fried Oreochromis niloticus, Mugilcephalus and Sardinops sagax where the values recorded for cadmium are 0.021 $\mu \mathrm{g} / \mathrm{g}, 0.360 \mu \mathrm{g} / \mathrm{g}$ and $0.821 \mu \mathrm{g} / \mathrm{g}$; As for lead, the values are respectively $0.011 \mu \mathrm{g} /$ g, $0.011 \mu \mathrm{g} / \mathrm{g}$ and $0.022 \mu \mathrm{g} / \mathrm{g}$. For copper, the values obtained are respectively $0.48 \mu \mathrm{g}$ / g, $0.89 \mu \mathrm{g} / \mathrm{g}$ and $1.13 \mu \mathrm{g} / \mathrm{g}$ and finally those of zinc $6.45 \mu \mathrm{g} / \mathrm{g}, 8.97 \mu \mathrm{g} / \mathrm{g}$ and 13,
$86 \mu \mathrm{g} / \mathrm{g}$ respectively. Our values are also lower than the concentrations recorded by Devi and Sarojnalini [26] in Amblypharyngodon mola for copper $(0.023$ $\mu \mathrm{g} / \mathrm{g})$ and zinc $(0.96 \mu \mathrm{g} / \mathrm{g})$. Copper is an integral part of many enzymes and is needed for hemoglobin synthesis [23]. Zinc is an essential trace element that is a component of more than 300 enzymes needed to play a role in many biological functions of the human body. However, they become toxic when they exceed maximum limits [27].

The results of the effects of cooking methods on heavy metal concentrations obtained in fish are similar to those recorded by Ersoy and al. [28] on Dicentrarchus labrax species which have positive and negative effects on the heavy metal reduction according to cooking methods. On this same fish species, frying and microwave cooking showed an increase in cadmium and arsenic, while grilling and boiling showed a decrease in lead. Results obtained are also similar to those recorded by Bassey et al. [19] on three fish species analyzed in Nigeria. The cooking methods had a significant impact on cadmium levels in Cynoglossus senegalensis. In Polydactylus quadratifilis, boiling and frying led to an increase of cadmium concentration by $100 \%$, while grilling gave seven times the concentration of cadmium in fresh fish. In addition, the concentration 
of cadmium in Chrysicthys nigrodigitatus increased. The increase in cadmium during grilling and frying was obviously a result of water loss [29]. As for lead, its concentration in Polydactylus quadratifilis increased by $5.9 \%$ for boiling, $70.6 \%$ for grilling and $41.2 \%$ for frying. Boiling caused $32.6 \%$ decrease in lead concentration in Chrysicthys nigrodigitatus, while frying and grilling showed $2.2 \%$ and $4.2 \%$ increase in lead concentrations, respectively. On the other hand, the different cooking methods caused a decrease in the concentration of lead in Cynoglossus senegalensis. In fact, the levels of lead in boiled, grilled and fried Cynoglossus senegalensis decreased around $20.8 \%, 22.6 \%$ and $20.8 \%$ respectively.

\section{CONCLUSION}

In sum, this study assessed heavy metal contamination in imported frozen fish. The concentrations recorded in the various imported frozen fish species indicate that none of them exceeds the standards accepted by FAO and WHO. However, frequent consumption and the number of fish consumed per meal can increase the level of heavy metals in the body and could induce chronic toxicity for the consumer. As for the two cooking methods, they have both a positive and a negative effect on the reduction of heavy metal concentrations depending on fish species. Although the concentrations of heavy metals are not worrying, vigilance of the populations and variation of diets are important to guarantee a better health.

\section{BIBLIOGRAPHICAL REFERENCES}

[1] Houngbédji A., 2005. Il n'y a de richesse que d'hommes. Edition de l'Archipel, Paris, 239p.

[2] Noya E. C., Roux B., Lopes G. M. B., Maranhao E. A., 2010. Politiques publiques et réduction de l'usage des pesticides: la politique de vulgarisation auprès des agriculteurs familiaux dans le Nordeste du Brésil. Colloque SFER, $\mathrm{La}$ réduction des pesticides agricoles, enjeux, modalités et conséquences, E.N.S. Lyon, 14 p

[3] FAO/OMS, 2001. Les quantités de mauvaise qualité vendues dans les pays en développement sont alarmantes. Communiqué de presse OMS/04 1er février 2001. http : //www.who.int

[4] Charlier C. et Plomteux G., 2002. Pollution chimique de l'environnement et risque toxique pour l'homme. Le rôle particulier des dérivés pesticides organochlorés. Ann. Bio. Clin., 60 (1) : 37-46.

[5] AFSSA (Agence Francaise de Sécurité Sanitaire des Aliments), 2003. Institut de veille sanitaire. Le méthylmercure.

Programme 
"mortalité et morbidité des maladies

d'origine alimentaire"-Volet

toxicologique-Contaminants

chimiques et risque alimentaire en

France, document de travail, France, $65 p$.

[6] MAEP (Ministère de 1'Agriculture, de l'Elevage et de la Pêche), 2009. Statistiques de la Direction des Pêches, MAEP, Cotonou, Bénin, 57 p.

[7] Sohou Z., Houedjissin R. C., Ahoyo N. R. A., 2009. La pisciculture au Bénin : de la tradition à la modernisation, Bulletin de la Recherche Agronomique du Bénin. $66: 48-59$.

[8] Yehouenou E. A. P., LALEYE P., Michel B., Cornelis A.M.V.G., Hyacinthe A., Simon A., Bert V.H., Kees S., Nico M.V.S., $2006 a$. Contamination of fish organochlorine pesticide residues in the Ouémé River catchment in the Republic of Bénin. Environnement Int., 32: 594-5999.

[9] Yehouenou E. A. P., Boko M., Corneli, A.M.V.G., Hyacinthe A., Laleye P., Simon A., Bert V.H., Kees S., Nico M.V.S., 2006 b. Organochlorine and organophosphorous pesticide residues in the Ouémé River catchment in the
Republic of Bénin. Environnement Int., 32: 616-623.

[10] Vissin E.W., Sintondji L. O., Houssou S. C., 2010. Étude de la pollution des eaux et de la contamination du Tilapia guineensis du canal de Cotonou par le plomb. $R G L L, 08: 215-29$.

[11] Youssao A., Soclo H. H., Bonou C., Vianou K., Gbaguidi M., Dovonon L., 2011. Evaluation de la contamination de la faune ichthyenne dans le complexe lagunaire Nokoué-chenal de Cotonou par le plomb : cas des espèces Sarotherodon melanotheron, Tilapia guineensis et Hemichromis fasciatus (Bénin). Int. J. Biol. Chem. Sci. 5(2): 595-602.

[12] Hounkpatin A. S., Edorh A. P., Sèzonlin M., Guédénon P., Elégbédé B., Boni G., Dougnon V., Montcho S., Kéké E., Boko M., 2012. Pollution of aquatic ecosystems by heavy metals at Ganvié's lacustrine city (Benin). International Research Journal of Biotechnology, 3(6):81-87.

[13] Gbesso F. G. H., Akognongbe A. J. S., Vissin E. W., 2015. Contamination de tilapia guineensis par le cadmium dans le chenal de Cotonou. Revue de 
Géographie de l'Université de Ouagadougou, 1 (4): 23-42.

[14] Viala A. et Grimaldi F., 2005. Ecotoxicologie In :Viala A. et Botta A., Eléments de toxicologie, 2è Ed, Tec\& Doc Lavoisier, Paris, pp245-251.

[15] Kuznetsova A., Brockhoff P. B., Christensen R. H. B., 2017. MerTest Package: Tests in Linear Mixed Effects Models. Journal of statistical Software, 82 (13): 126.doi:10.18637/jss.v082.i13

[16] Russell V. L. 2016. Least-Squares Means: The R Package lsmeans. Journal of statistical Software, 69(1):1-33.doi :10.18637/jss.v069.i01

[17] Wickham H. 2016. ggplot2: Elegant Graphics for Data Analysis. Springer-Verlag, New York, 1-253 p.

[18] Taiyun W, Viliam S. 2017. R package "corrplot": Visualization of a Correlation Matrix (Version 0.84). Available from https: //github.com/taiyun/corrplot

[19] Bassey F. I., Oguntunde F. C., Iwegbue C. M. A., Osabor V. N., Edem C. A., 2014. Effects of processing on the proximate and metal contents in three fish species from Nigerian coastal waters.
Food Science \& Nutrition; 2(3): 272-281.

[20] Alturiqi A. S. and Albedair L. A., 2012. Evaluation of some heavy metals in certain fish, meat and meat products in Saudi Arabian markets. The Egyptian Journal of Aquatic Research, 38(1): 45-49.

[21] Abubakar A., Uzairu A., Ekwumemgbo P. A., Okunola O. J., 2015. Risk Assessment of Heavy Metals in Imported Frozen Fish Scomberscombrus Species Sold in Nigeria: A Case Study in Zaria Metropolis. Hindawi Publishing Corporation Advances in Toxicology, 2015 (303245):111.

http://dx.doi.org/10.1155/2015/303 245

[22] Oluyemi E. A. et Olabanji I. O., 2011. Heavy metals determination in some species of frozen fish sold at ile-ife main market, south west nigeria. Ife Journal of Science. 13(2): 355-362.

[23] Huque R., Munshi M. K., Khatun A., Islam M., Hossain A., Hossain A., Akter S., Kabir J., Jolly Y. N., Islam A., 2014. Comparative Study of Raw and Boiled Silver Pomfret Fish from Coastal Area and Retail Market in Relation to Trace Metals and Proximate 
Composition. International

Journal of Food Science, 2014:1-6.

[24] Obodai E.A., Boamponsem L.K., Adokoh C.K., Essumang D.K., Villawoe B.O., Aheto D.W., Debrah, J.S., 2011. Concentrations of heavy metals in two Ghanaian Lagoons. Archives of Applied Science Research, 3 (3):177-187.

[25] Tawfik M.S., 2013. Impact of different coocking processes on proximate metals composition of fish and shrimp. Journal of Food Technology, 11(4-6): 95-102.

[26] Devi W. S. and Sarojnalini Ch., 2012. Impact of different cooking methods on proximate and mineral composition of amblypharyngodon mola of manipur. International Journal of Advanced Biological Research, 12 (4):712-716.

[27] Das M. and Das R., 2012. Need of education and awareness towards zinc supplementation: a review. International Journal of Nutrition and Metabolism, 4(3):45-50.

[28] Ersoy B., Yanar Y., Küçükgülmez A., Çelik M., 2006. Effects of four cooking methods on the heavy metal concentrations of sea bass fillets (Dicentrarchus labrax Linne, 1785). Food Chemistry, 99(4) :748-751.

[29] Kalogeropoulos N., Karavoltsos S., Sakellari A., Avramidou S., Dassenakis N., and Scoulla M., 2012: Heavy metals in raw, fried and grilled Mediterranean finfish and shellfish. Food Chem. Toxicol. 50:3702-3708. 